\title{
Body response to primary joint replacement after proximal femur injuries in patients with an increased body mass index (preliminary study)
}

\author{
H.Zh. Han ${ }^{1}$, I.F. Akhtiamov ${ }^{1}$, G.G. Garifullov ${ }^{2}$, G.M. Faizrakhmanova ${ }^{1}$, R.G. Kuznetsova ${ }^{2}$ \\ ${ }^{1}$ Kazan State Medical University, Kazan, Russian Federation \\ ${ }^{2}$ Republican Clinical Hospital of the Ministry of Health of the Republic of Tatarstan, Kazan, Russian Federation
}

\begin{abstract}
Introduction Injuries of the proximal femur remains a significant problem of management in the elderly persons. The traditional approach comprising osteosynthesis of bone fragments is a method of choice in standard situations but showed to be insufficient in patients with an increased body mass index (BMI). Significant delay in full weight-bearing walking ability in this group of patients after fixation with dynamic systems needs to be solved with a non-standard approach to their treatment. Therefore, arthroplasty after fractures of the proximal femur allows us to hope for an improved walking already in the early stages of rehabilitation in such a difficult group of patients. Methods Early results of hip replacement in 52 patients with fractures of the proximal femur were analyzed. They were divided into two groups: group I with obesity (28 cases, BMI $\geqslant 25$ ) and group II with a normal body weight (24 cases, BMI < 25). Intraoperative and postoperative hemoglobin and blood loss counts, duration of the operation, frequency of early complications and the Harris hip score at six and 12 months after surgery were compared. Results Statistical analysis of the parameters showed a significant relationship between overweight, duration of the operation and blood loss, as well as clinical and functional treatment outcomes at six months after joint replacement measured with HHS scale $(\mathrm{p}<0.05)$. Significant efficiency of arthroplasty was revealed in the rehabilitation period. Conclusion Obesity complicates hip arthroplasty but significantly affects the body response of patients with injuries in the hip area only in the early stages of treatment.
\end{abstract}

Keywords: arthroplasty, obesity, fracture, proximal femur

\section{INTRODUCTION}

The World Health Organization (WHO) has declared a pandemic of obesity as the number of obese people in both developed and developing countries has increased over the last three decades. [1]. It has been estimated that there is a total of 1.4 billion overweight people (35\% of the world's population) and 500 million obese people (11\%) [2].The growth in the incidence has been associated with several etiological factors, including an unhealthy, sedentary lifestyle and unbalanced or hypercaloric nutrition [2]. Obesity is a risk factor for the development of Type 2 diabetes mellitus, cardiovascular and oncological diseases, and pathologies of the digestive, reproductive and musculoskeletal systems [3].
Joint replacement, especially hemi-arthroplasty, has become an integral element in the treatment of patients with injuries of the hip joint. High efficiency, a low risk of complications and an early activity of patients after the interventions are the factors that make arthroplasty popular. At the same time, a background of comorbidities in elderly patients poses a number of problems for the doctor and requires increased attention to the inpatient phase of treatment. One of the issues which is little studied in arthroplasty is the impact of overweight, which was considered a relative contraindication to arthroplasty in the era of the method establishment.

Purpose To study the impact of overweight on the duration of the rehabilitation period after bipolar hip replacement in patients with proximal femur injury.

\section{MATERIAL AND METHODS}

The study was conducted at the department of the Republican Clinical Hospital of the Ministry of Health of the Republic of Tatarstan in Kazan between March 2017 and March 2018. It met the rules and conditions of the Helsinki declaration of the World Health Organization on Ethical Principles for Medical Research Involving Human Subjects amended in 2000 and Rules of Clinical Practice in the Russian Federation adopted by the ministry of health of the Russian Federation on 19.06.2003, order 266. Medical documentation of fifty-two patients with fractures of the proximal femur who 
underwent hemiarthroplasty with a bipolar implant and cement fixation of the femur component was studied (Table 1).

Patients were assigned to groups according to their BMI [2]. There were 24 (46.15\%) individuals with normal BMI and 28 (53.85 \%) overweight patients (Table 2).

Thus, the average BMI in the main group was $28.7 \pm 4.15$, and in the comparison group $22.4 \pm 1.8$.

A number of parameters were assessed during the inpatient phase of treatment and during the rehabilitation period up to 12 months after the injury. It included a comparative analysis of the duration of the intervention (minutes), intraoperative and postoperative volume of blood loss (ml), length of hospital stay (bed-days), the Harris index (points) and complications in the periods of six and 12 months after the operation.

Statistical analysis was performed with software package SPSS 19.0, STATISTICA 10. The sample was checked for normal distribution using the Kolmogorov-Smirnov criterion. Quantitative results are presented as $M \pm S D$, where $M$ is the sample mean, SD is the standard deviation. The significance of differences was determined using the parametric T-test and non-parametric test $\chi^{2}$. A critical level of significance in statistical hypotheses in this study was taken at $\mathrm{p}<0.05$.

Table 1

Anthropometric data

\begin{tabular}{|l|l|}
\hline Sex & males: $\mathrm{n}=5(9.6 \%) ;$ females: $\mathrm{n}=47(90.4 \%)$ \\
\hline Age & 80.5 years $(67-93$ years $)$ \\
\hline Involved side & Left hip joint $-31(59.6 \%)$; right hip joint $-21(40.4 \%)$ \\
\hline Weight (min - max) & $67.4 \mathrm{~kg}(48-120)$ \\
\hline Height $(\min -\max )$ & $161.7 \mathrm{~cm}(155-175)$ \\
\hline BMI $(\min -\max )$ & $25.81 \mathrm{~kg} / \mathrm{m} 2(18.7-48.8)$ \\
\hline
\end{tabular}

Table 2

Distribution of patients according to BMI

\begin{tabular}{|l|c|c|c|c|c|c|c|}
\hline \multirow{2}{*}{ Groups } & \multirow{2}{*}{$\begin{array}{c}\text { Number of patients } \\
(\mathrm{n} / \%)\end{array}$} & \multicolumn{3}{c|}{ Males } & \multicolumn{3}{c|}{ Females } \\
\cline { 3 - 8 } & & Abs. & $\%$ & $\begin{array}{c}\text { Mean age, } \\
\mathrm{M} \pm \mathrm{m}\end{array}$ & Abs. & $\begin{array}{c}\text { Mean age, } \\
\mathrm{M} \pm \mathrm{m}\end{array}$ \\
\hline BMI $(\geqslant 25$ to $<30)$ & $22 / 42.3$ & 2 & 3.8 & $85.5 \pm 2.5$ & 20 & 38.5 & $81.3 \pm 5.9$ \\
\hline BMI $(\geqslant 30$ to $<35)$ & $5 / 9.6$ & 1 & 2 & 83 & 4 & 7.7 & $86.0 \pm 3.5$ \\
\hline BMI $(\geqslant 35$ to $<40)$ & 0 & 0 & 0 & 0 & 0 & 0 & 0 \\
\hline BMI $(\geqslant 40)$ & $1 / 2$ & 0 & 0 & 0 & 1 & 2 & 74 \\
\hline Norm $(\geqslant 18.5$ to $<25)$ & $24 / 46.1$ & 2 & 3.8 & $77.5 \pm 9.5$ & 22 & 42.2 & $78.9 \pm 7.0$ \\
\hline Total & $52 / 100$ & 5 & 9.6 & $81.8 \pm 7.2$ & 47 & 90.4 & $80.4 \pm 6.6$ \\
\hline
\end{tabular}

\section{RESULTS}

There was no significant difference between the hemoglobin level, length of hospital stay, and the two groups in a number of parameters: duration of rate of intra- and early postoperative complications the intervention, preoperative and postoperative (Table 3).

Table 3

Comparison of clinical parameters of inpatient treatment for bipolar arthroplasty in patients with fractures of the proximal femur

\begin{tabular}{|c|c|c|c|c|c|c|c|}
\hline \multirow{2}{*}{$\begin{array}{l}\text { Group } \\
\text { (BMI) } \\
\mathrm{kg} / \mathrm{m}^{2}\end{array}$} & \multirow{2}{*}{$\begin{array}{l}\text { Number of } \\
\text { cases (n) }\end{array}$} & \multirow{2}{*}{$\begin{array}{l}\text { Duration of } \\
\text { operation } \\
\text { (min) }\end{array}$} & \multirow{2}{*}{$\begin{array}{l}\text { Blood loss } \\
\quad(\mathrm{ml})\end{array}$} & \multirow{2}{*}{$\begin{array}{c}\text { Total blood } \\
\text { loss (ml) }\end{array}$} & \multirow[b]{2}{*}{ Bed-days } & \multicolumn{2}{|c|}{ Hemoglobin (g/dl) } \\
\hline & & & & & & $\begin{array}{l}\text { Before } \\
\text { operation }\end{array}$ & $\begin{array}{c}\text { After } \\
\text { operation }\end{array}$ \\
\hline $\mathrm{BMI} \geqslant 25$ & 28 & $73.0 \pm 15.1$ & $230.2 \pm 79.5$ & $783.4 \pm 94.1$ & $9.4 \pm 2.6$ & $11.7 \pm 1.6$ & $9.8 \pm 1.7$ \\
\hline $\mathrm{BMI}<25$ & 24 & $70 \pm 12.2$ & $183.3 \pm 51.2$ & $709.6 \pm 64.8$ & $10.1 \pm 1.9$ & $11.8 \pm 1.4$ & $9.7 \pm 1.5$ \\
\hline$p$ & & $p>0.05$ & $p<0.05$ & $p<0.01$ & $p>0.05$ & $p>0.05$ & $p>0.05$ \\
\hline
\end{tabular}


Six months after the intervention, the first HHS evaluation was calculated in both groups. It was evident it did not exceed 20 points due to immobility and pain immediately after the injury, but upon discharge from the hospital the pain subsided, the patients started to ambulate independently with additional means of support. By the end of the first half of the year post-surgery, the HHS was $76.6 \pm 3.3$ in group I (main group) and $74.6 \pm 2.7$ in group II (comparison group). At this intermediate follow-up, the difference was statistically significant $(p<0.05)$. Further examination showed that the differences in functional ability 12 months after the surgery disappeared, and all patients achieved relatively equal functions (Fig. 1).

Implant survival at the last follow-up was $100 \%$.

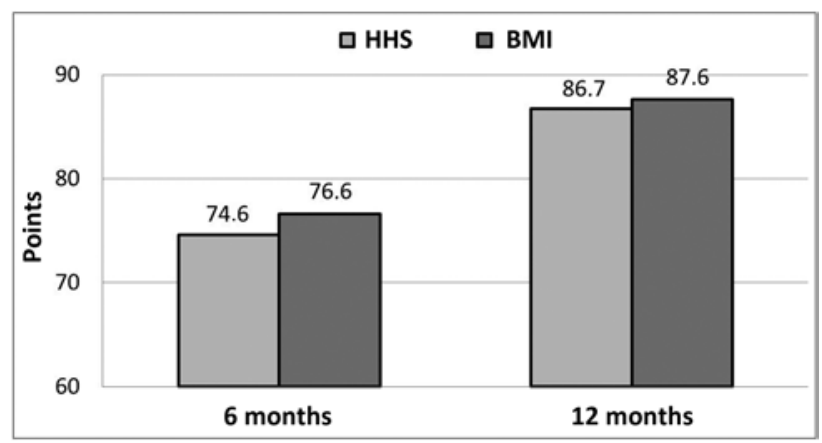

Fig. 1 Functional outcomes according to HHS at follow-ups

\section{DISCUSSION}

The goal of hip replacement is to alleviate pain, restore or improve joint function, and correct deformity. Obesity was considered previously a relative contraindication [4] for arthroplasty. K.M. Sivash opined that overweight had a negative impact in joint replacement. With improved surgical techniques and anesthesia, implants and materials, the list of contraindications to total hip arthroplasty has changed [5, 6].

Most patients of the main group had an excessive body weight (22 patients). Thus, the groups matched in number and height-to-weight characteristics. It enabled to reliably make the comparison of bipolar arthroplasty.

Statistical analysis showed that a large surface of adipose tissue exposed during implantation of the prosthesis leads to higher total blood loss in overweight patients. It should be noted that this was confirmed in our study by a significant relationship between an increased BMI and intraoperative, and, accordingly, total blood loss ( $\mathrm{p}<0.05)$, but there was no statistical evidence regarding postoperative losses along the drainage systems. Thus, we can state that overweight affects the level of intra-operative and total blood loss.

As for gender differences, it should be noted that in males the volume of subcutaneous tissue in the hip joint region did not differ in both groups, which cannot be said about women. Accordingly, we did not find a significant difference in both intra-operative and total blood loss when installing bipolar endoprostheses in males. Since the total number of males was low, this did not have any impact on the conclusion of the study.

Hemoglobin levels did not have statistical difference in both groups at the time the injured were admitted to the hospital; and almost all of them had anemia due to severe trauma. However, the publication of Y. Qin et al. [7] reported that patients with obesity have higher levels of ferrum-deficient anemia than those with normal BMI. The main factors associated with obesity cause an increased regulation of hepcidin, which inhibits the absorption of iron [8]. Anemia is a risk factor for postoperative complications; therefore, during perioperative preparation, anemia should be corrected to reduce the risk of surgical intervention and a possible development of hypovolemic shock.

Publications on the subject of this study report a higher incidence of peri-operative complications of hip replacement in obesity: dislocations, infections, aseptic loosening and venous thromboembolism [9, 10], as well as superficial or deep infection [11]. In our study, after hemiarthroplasty, the rates of complications were 8.3 and $10.7 \%$, respectively. There were more of them in the main group than in the group with normal BMI, but the difference was not statistically significant $(\mathrm{p}>0.05)$ (Table 4$)$. 
Postoperative complications in the groups

\begin{tabular}{|l|c|c|c|c|}
\hline & Number of cases (n) & Infection & Venous thromboembolism & Total of complications \\
\hline $\mathrm{BMI} \geqslant 25$ & 28 & 2 & 1 & 3 \\
\hline $\mathrm{BMI}<25$ & 24 & 2 & 0 & 2 \\
\hline$\chi^{2}$ & & 0.026 & 0.874 & 0.084 \\
\hline $\mathrm{P}$ & & $0 / 872$ & 0.350 & 0.772 \\
\hline
\end{tabular}

There were no cases of implant dislocation despite the anterolateral approach to the joint was used. Undoubtedly, it was due to the use of bipolar implant type. After three to six months, the external sphere of the pelvic component was fixed with scar tissue in a definite position that decreased the risk of disposition. After 12 months, there were no cases of femoral component instability; that was to some extent due to a relatively limited functional activity of the patients because of their age.

Analyzing the details of the study, one should consider that some opinions might be erroneous as the samples in both groups were small.

There are different opinions about the impact of excessive weight on the restoration of functionality after joint replacement, both total and unipolar. E. Yeung et al. [12] believe that obesity does not affect the restoration of post-operative mobility in the hip joint, and active rehabilitation is the key to a positive outcome. We opine that this judgment is correct, despite certain differences in the functional abilities of the patients of the groups at the intermediate follow-up.

\section{CONCLUSION}

Despite the relatively small number of patients in this study, we revealed a certain tendency in the analysis of the response of the injured to joint replacement immediately after proximal femur fractures. Being overweight had a certain impact on the course of the inpatient treatment phase and the intermediate functional result, while recovery after completion of the rehabilitation course (after a period of more than 12 months) is characteristic of patients of both the groups, with normal weight and overweight. The overall positive outcome of the treatment in patients with fractures of the proximal femur of the main group leaves no doubt about the need for hemi-arthroplasty in these cases, taking into account possible intra- and postoperative complications.

\section{Funding and Conflict of Interest Information}

The study did not have any sponsorship.

The authors declare no apparent or potential conflicts of interest related to the publication of this article.

\section{REFERENCES}

1. Ng M., Fleming T., Robinson M., Thomson B., Graetz N., Margono C., Mullany E.C., Biryukov S., Abbafati C., Abera S.F., Abraham J.P., Abu-Rmeileh N.M., Achoki T., AlBuhairan F.S., Alemu Z.A., Alfonso R., Ali M.K., Ali R., Guzman N.A., Ammar W., Anwari P., Banerjee A., Barquera S., Basu S., Bennett D.A., Bhutta Z., Blore J., Cabral N., Nonato I.C., Chang J.C., Chowdhury R., Courville K.J., Criqui M.H., Cundiff D.K., Dabhadkar K.C., Dandona L., Davis A., Dayama A., Dharmaratne S.D., Ding E.L., Durrani A.M., Esteghamati A., Farzadfar F., Fay D.F., Feigin V.L., Flaxman A., Forouzanfar M.H., Goto A., Green M.A., Gupta R., Hafezi-Nejad N., Hankey G.J., Harewood H.C., Havmoeller R., Hay S., Hernandez L., Husseini A., Idrisov B.T., Ikeda N., Islami F., Jahangir E., Jassal S.K., Jee S.H., Jeffreys M., Jonas J.B., Kabagambe E.K., Khalifa S.E., Kengne A.P., Khader Y.S., Khang Y.H., Kim D., Kimokoti R.W., Kinge J.M., Kokubo Y., Kosen S., Kwan G., Lai T., Leinsalu M., Li Y., Liang X., Liu S., Logroscino G., Lotufo P.A., Lu Y., Ma J., Mainoo N.K., Mensah G.A., Merriman T.R., Mokdad A.H., Moschandreas J., Naghavi M., Naheed A., Nand D., Narayan K.M., Nelson E.L., Neuhouser M.L., Nisar M.I., Ohkubo T., Oti S.O., Pedroza A., Prabhakaran D., Roy N., Sampson U., Seo H., Sepanlou S.G., Shibuya K., Shiri R., Shiue I., Singh G.M., Singh J.A., Skirbekk V., Stapelberg N.J., Sturua L., Sykes B.L., Tobias M., Tran B.X., Trasande L., Toyoshima H., Van de Vijver S., Vasankari T.J., Veerman J.L., VelasquezMelendez G., Vlassov V.V., Vollset S.E., Vos T., Wang C., Wang X., Weiderpass E., Werdecker A., Wright J.L., Yang Y.C., Yatsuya H., Yoon J., Yoon S.J., Zhao Y., Zhou M., Zhu S., Lopez A.D., Murray C.J., Gakidou E. Global, regional, and national prevalence of overweight and obesity in children and adults during 1980-2013: a systematic analysis for the Global Burden of Disease Study 2013. Lancet, 2014, vol. 384, no. 9945, pp. 766-781. DOI: 10.1016/S0140-6736(14)60460-8.

2. Obesity: preventing and managing the global epidemic: report of a WHO consultation. Geneva, Switzerland: WHO Consultation on Obesity, 2000, 252 p. 
3. Iuosef A.I., Akhtiamov I.F. Osobennosti artroplastiki u patsientov s izbytochnoi massoi tela (obzor literatury) [Specific features of arthroplasty in patients with overweight (Review of the literature)]. Travmatologiia i Ortopediia Rossii, 2017, vol. 23, no. 2, pp. 115-123. DOI: 10.21823/2311-2905-2017-23-2-115-123. (in Russian)

4. Andrew J.G., Palan J., Kurup H.V., Gibson P., Murray D.W., Beard D.J. Obesity in total hip replacement. J. Bone Joint Surg. Br., 2008, vol. 90, no. 4, pp. 424-429. DOI: 10.1302/0301-620X.90B4.20522.

5. Kramer D.B., Xu S., Kesselheim A.S. Regulation of medical devices in the United States and European Union. N. Engl. J. Med., 2012, vol. 366, no. 9, pp. 848-855. DOI: 10.1056/NEJMhle1113918.

6. Shetty V., Shitole B., Shetty G., Thakur H., Bhandari M. Optimal bearing surfaces for total hip replacement in the young patient: a meta-analysis. Int. Orthop., 2011, vol. 35, no. 9, pp. 1281-1287. DOI: 10.1007/s00264-010-1104-7.

7. Qin Y., Melse-Boonstra A., Pan X., Yuan B., Dai Y., Zhao J., Zimmermann M.B., Kok F.J., Zhou M., Shi Z. Anemia in relation to body mass index and waist circumference among Chinese women. Nutr. J., 2013, vol. 12, pp. 10. DOI: 10.1186/1475-2891-12-10.

8. Tussing-Humphreys L., Pusatcioglu C. , Nemeth E., Braunschweig C. Rethinking iron regulation and assessment in iron deficiency, anemia of chronic disease, and obesity: introducing hepcidin. J. Acad. Nutr. Diet., 2012, vol. 112, no. 3, pp. 391-400. DOI: 10.1016/j.jada.2011.08.038.

9. Workgroup of the American Association of Hip and Knee Surgeons Evidence Based Committee. Obesity and total joint arthroplasty: a literature based review. J. Arthroplasty, 2013. Vol. 28, No 5. P. 714-721. DOI: 10.1016/j.arth.2013.02.011.

10.Haverkamp D., Klinkenbijl M.N., Somford M.P., Albers G.H., Van der Vis H.M. Obesity in total hip arthroplasty - does it really matter? A meta-analysis. Acta Orthop., 2011, vol. 82, no. 4, pp. 417-422. DOI: 10.3109/17453674.2011.588859.

11.Wagner E.R., Kamath A.F., Fruth K.M., Harmsen W.S., Berry D.J. Effect of body mass index on complications and reoperations after total hip arthroplasty. J. Bone Joint Surg. Am., 2016, vol. 98, no. 3, pp. 169-179. DOI: 10.2106/JBJS.O.00430.

12. Yeung E., Jackson M., Sexton S., Walter W., Zicat B., Walter W. The effect of obesity on the outcome of hip and knee arthroplasty. Int. Orthop., 2011, vol. 35, no. 6, pp. 929-934. DOI: 10.1007/s00264-010-1051-3.

Received: 18.04.2019

\section{Information about authors:}

1.Hao Zhi Han, Kazan State Medical University, Kazan, Russian Federation, Email: hanhaozhi723@hotmail.com

2.Ildar F. Akhtiamov, M.D., Ph.D., Professor, Kazan State Medical University, Kazan, Russian Federation

3. Gamil G. Garifullov, M.D., Ph.D., Republican Clinical Hospital of the Ministry of Health of the Republic of Tatarstan, Kazan, Russian Federation

4. Gulnara M. Faizrakhmanova, M.D., Ph.D., Kazan State Medical University, Kazan, Russian Federation

5. Roza G. Kuznetsova, SAHI Republican Clinical Hospital of the Ministry of Health of the Republic of Tatarstan, Kazan, Russian Federation 